\title{
Association of various types of epibacteria with Halicryptus spinulosus (Priapulida)
}

\author{
Rolf Oeschger, Rolf Schmaljohann
}

Institut für Meereskunde an der Universität Kiel, Düsternbrooker Weg 20, D-2300 Kiel 1, Federal Republic of Germany

\begin{abstract}
The priapulid worm Halicryptus spinulosus von Siebold, from a sulfide-rich brackish water habitat, is associated with various types of epibacteria. TEM observations reveal bacteria morphologically similar to Thiobacillus and Leucothrix/Thiothrix. The Thiobacillus-type is the dominant organism; it occurs in microcolonies throughout the bacterial layer and frequently contains carboxysomes, which are indicative of chemoautotrophic activity. Analyses of ribulose-1,5-bisphosphate carboxylase, X-ray microanalysis, and the ratio of stable ${ }^{13} \mathrm{C} /{ }^{12} \mathrm{C}$ and ${ }^{15} \mathrm{~N} /{ }^{14} \mathrm{~N}$ isotopes do not indicate a participation of chemoautotrophic bacteria in the nutrition of the worm. It is concluded that the epibacteria might be able to detoxify the hydrogen sulfide to some degree, provided oxygen or nitrate is available, and that the worms must rely on their own metabolism of hydrogen sulfide detoxification whenever their environment becomes anoxic.
\end{abstract}

\section{INTRODUCTION}

Halicryptus spinulosus, a marine priapulid with an exceptionally high resistance to anoxia (Oeschger 1987 ) inhabits sediments with high hydrogen sulfide content in brackish waters of the Baltic Sea. Several marine invertebrates are known to survive in the presence of considerable amounts of ambient hydrogen sulfide (e.g. Theede et al. 1969). For H. spinulosus electron microscopic investigations revealed an association with epibacteria. A morphologically similar association was observed, for example, on the polychaete Alvinella pompejana (Desbryuères et al. 1983). In the rhizosphere of rice plants, ectobacteria serve as protection against hydrogen sulfide (Joshi \& Hollis 1977. Heritage \& Foster 1984). Powell et al. (1979) discussed a similar function for epibacteria associated with meiofauna.

This paper presents studies on an association of epibacteria with Halicryptus spinulosus. Transmission electron microscopy, enzyme assays, X-ray analysis and stable isotope measurements have been used in order to clarify the role of these bacteria. We were interested to find an answer to the question, whether these bacteria participate in detoxifying the hydrogen sulfide, or whether the worms themselves are able to metabolize this substance to non-toxic compounds.

\section{MATERIAL AND METHODS}

Sampling. The priapulid Halicryptus spinulosus von Siebold was collected in August and December 1986 in Kiel Bight (Western Baltic Sea) with a triangular naturalist's dredge or a Van Veen grab from a water depth of $21 \mathrm{~m}$ at a salinity of about $22 \%$. The sampling area in Kiel Bight is characterized by low oxygen concentrations and an often high hydrogen sulfide content in the muddy sediment, particularly during summer and autumn (Oeschger \& Theede 1988).

Transmission electron microscopy (TEM). The worms were fixed with $3 \%$ glutaraldehyde in $60 \mathrm{mM}$ phosphate buffer containing $7.5 \%$ sucrose $\left(2 \mathrm{~h}, 5^{\circ} \mathrm{C}\right)$. After rinsing with phosphate buffer, they were postfixed with $2 \% \mathrm{OsO}_{4}$ in phosphate buffer $(2 \mathrm{~h})$, dehydrated in a graded ethanol series and in propylene oxide, and embedded in Spurr's resin. Ultra-thin sections were stained with uranyl acetate and lead citrate, and examined with a Zeiss EM 9 electron microscope. $X$-ray microanalysis was performed with unstained carbon-coated sections of $10 \mathrm{~nm}$ thickness in a Philips EM 400 T electron microscope fitted with a CEVEX microprobe.

Enzyme assay. In order to empty their guts, the worms were kept in a sediment-free aquarium for $5 \mathrm{~d}$ prior to autotrophic capability experiments. Body wall 
tussue of the worms was homogenized with an ultrasonıc device in 1 ce-cold $0.2 M$ Tris- $\mathrm{HCl}$ buffer $(\mathrm{pH}$ 8.0), contalning $1 \%$ Triton $x-100$. Ribulose-1,5-bisphosphate carboxylase (3-phospho-D-glycerate-carboxy-lyase, E.C. 4.1.1.39) was determined employing a method modified after Glover \& Morns (1979) and Dando et al (1985)

A reaction mixture was prepared from $50 \mu \mathrm{l}$ of homogenate, and $50 \mu \mathrm{l}$ of an assay solution containing $50 \mathrm{mM}$ Tris- $\mathrm{HCl}$ buffer $(\mathrm{pH} 8.0), 80 \mathrm{mM} \mathrm{NaHCO}$, $20 \mathrm{mM}$ reduced glutathione and $20 \mathrm{mM} \mathrm{MgCl}$. The preparation of this reaction mixture was performed in scintillation vials flushed with nitrogen immediately afterwards. Then $100 \mu \mathrm{l} \mathrm{NaH}^{14} \mathrm{CO}_{3}\left(60.4 \mu \mathrm{Cl} \mathrm{mmol}{ }^{-1}\right)$ were added, and the mixture was flushed again with nitrogen. After $10 \mathrm{~min}$ activation time at room temperature, $20 \mu \mathrm{I}$ of ribulosebisphosphate $(15 \mathrm{mM})$ were added. The reaction was stopped after 75 min with 500 ul of a mixture of glacial acetic acid and methanol (1 20). The acidified solutions were then dried at room temperature, reacidified with $200 \mu \mathrm{l}$ glacial acetıc acid, redried, and finally $5 \mathrm{ml}$ of scintillation liquid were added. Homogenized tissue of the red algae Phycodris rubens served as a reference for measuring the activity of ribulose-1,5-bisphosphate carboxylase. In all cases, samples of homogenates were incubated without the addition of substrate, ribulosebisphosphate, in order to

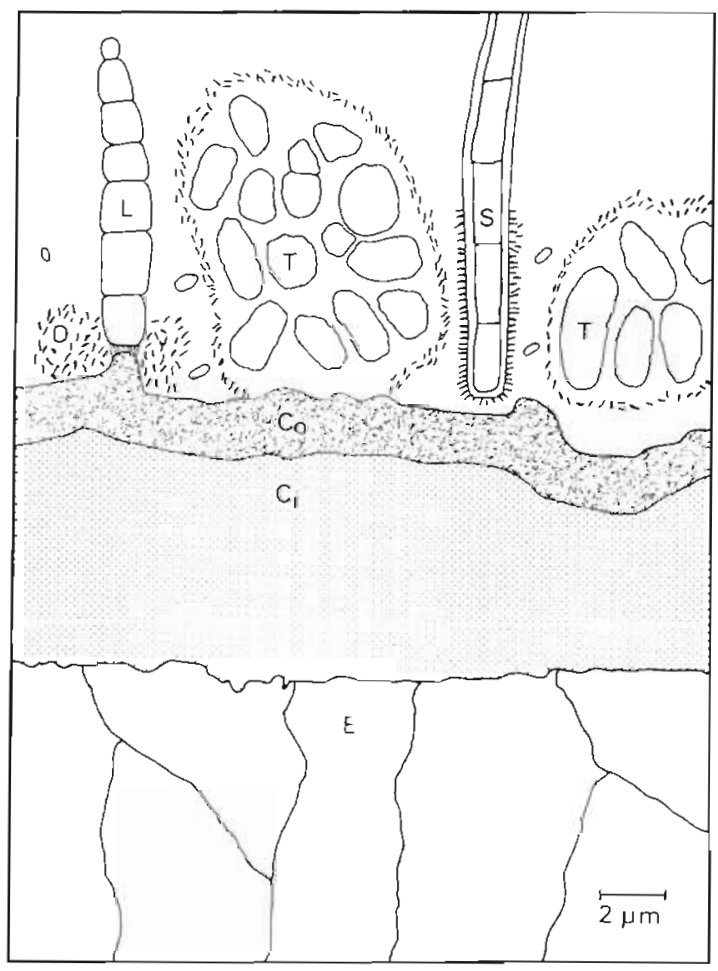

Fig 1 Integument of Halicryptus spinulosus $E$ epithelial cells, $C_{1}$ inner cuticle. $C$ () outer cuticle. T Thiobacillus-like bacteria, L Leucothrix/Thiothrux-like bactera, $\mathrm{S}$ sheathforming bacterial fulaments, D mineral depositions determine the amount of activity due to enzymes other than ribulose-1,5-bisphosphate carboxylase. For each homogenate, 3 replicates were performed.

Stable isotope measurements. For analysing stable carbon and nitrogen isotopes, tissue samples from Halicryptus spinulosus, Arctica islandica (which served as a comparison species, because it lacks chemoautotrophic symbionts as confirmed by Spiro et al. 1986), and sediment from the collection site were dried for several days at $60^{\circ} \mathrm{C}$. For carbon isotope analysis, sediment samples were acidified to eliminate carbonates. Werghed samples were oxidized with $\mathrm{CuO}$ at $900^{\circ} \mathrm{C}$, and the resulting carbon dioxide was subsequently trapped for carbon isotope determinations. The analyses were carrled out using a Varian MAT 250 ratio mass spectrometer, and the results are presented as $\delta$ values. For analysis of the ${ }^{15} \mathrm{~N} /{ }^{14} \mathrm{~N}$ ratio, the samples were combusted in a CHN-O-Rapid elemental analyser (Heraeus) at $950^{\circ} \mathrm{C}$. The resulting nitrous oxides were reduced to $\mathrm{N}_{2}$ in a copper reactor after the Dumas prnciple. Nitrogen was adsorbed to a molecular sieve by cooling with liquid nitrogen. Afterwards, the copper rod was warmed up and the gaseous nitrogen passed through a 'delta e' gas isotope mass spectrometer (Finnigan, MAT).

The isotope abundance was recorded as follows:

$$
\begin{gathered}
X=\left(\frac{R_{\text {Sample }}}{R_{\text {Standard }}}-1\right) \times 1000(\% \circ) \\
R=\frac{{ }^{13} \mathrm{C}}{{ }^{12} \mathrm{C}} \text { or } \quad R=\frac{{ }^{15} \mathrm{~N}}{{ }^{14} \mathrm{~N}} \\
X=\delta^{13} \mathrm{C} \text { or } \quad \delta^{15} \mathrm{~N}
\end{gathered}
$$

The standards used were Peedee belemnite (PDB) for carbon, and aur for nitrogen isotope analyses.

\section{RESULTS}

\section{Transmission electron microscopy}

The cuticle of Halicryptus spinulosus consists of a $2 \mu \mathrm{m}$ thick electron-dense outer layer and a thicker, 6 to $8 \mu \mathrm{m}$, electron-transparent inner layer (Fig. 1). It is covered by a bacterial layer 10 to $30 \mu \mathrm{m}$ thick, composed of several types of bacteria, mucous material and mineral precipitates (Fig. 2).

The bactera may occur as microcolonies, filaments or as single cells within the layer. Three distinct morphological types of bacteria were found in addition to several uncharacteristic small forms:

(a) Large rods $(1.0 \times 2.0$ to $3.0 \mu \mathrm{m})$, which occur in small microcolonies not exceeding about 100 cells (Fig. 3). These bacteria are surrounded by an undulating cell 
wall giving the cell surface a rippled appearance. Outside the nuclear region, they are filled with numerous small electron-dense granules, probably ribosomes. Polyhedral bodies of varying sizes are frequently found in the cytoplasm (Fig. 4).

(b) Filamentous bacteria, consisting of barrel-like cells with a diameter of 0.8 to $1.0 \mu \mathrm{m}$ and a length between 1 and 2 cell diameters (Figs. 2, 7 to 10). The filaments are always clearly constricted at the cell septa, and sometimes normal cells and rounded up cells, as shown in Fig. 9, occur within 1 filament. The filaments are not surrounded by a sheath. Frequently, cells ultrastructurally identical to the rounded-up cells are found beside the filament (Fig. 9), as well as similar bacteria which have undergone 1 or 2 unequal cell divisions (Fig. 11). These cells may have separated from the filament, and started to build new filaments, after attaching with a holdfast. Holdfasts fix directly to the outer layer of the cuticle (Fig. 8) or elsewhere (Fig. 7). The structure of the normal Gram-negative cell wall of the bacteria changes in the area of the holdfast; a wide peripalsmic space exists at those parts of the basal cell where holdfast material is excreted (Figs. 7 and 8). Fibrous extensions of the cell wall are often observed in the basal region of a filament (Fig. 7). The bacteria of this filamentous type frequently possess internal membranes, either as single lamellae of tubes running parallel to the cell membrane, or as vesiclelike structures (Figs. 7 and 10).

(c) Filamentous bacteria with a diameter of 0.4 to 0.5 $\mu \mathrm{m}$. These cells are between 1.0 and $2.2 \mu \mathrm{m}$ long, and filaments are not constricted at the cell septa (Fig. 6). Electron-dense storage products of unknown nature are found in most of these cells. In contrast to Type (b) filaments, these are surrounded by a sheath which is 0.8 to $0.9 \mu \mathrm{m}$ wide and sometimes covered with a layer of radially oriented mineral precipitates (Fig. 5). The space between cell wall and sheath shows a regular radial fine structure and small vesicles, presumably being transported from the cell wall to the outside of the sheath (Fig. 6). This type of filament has no holdfasts.

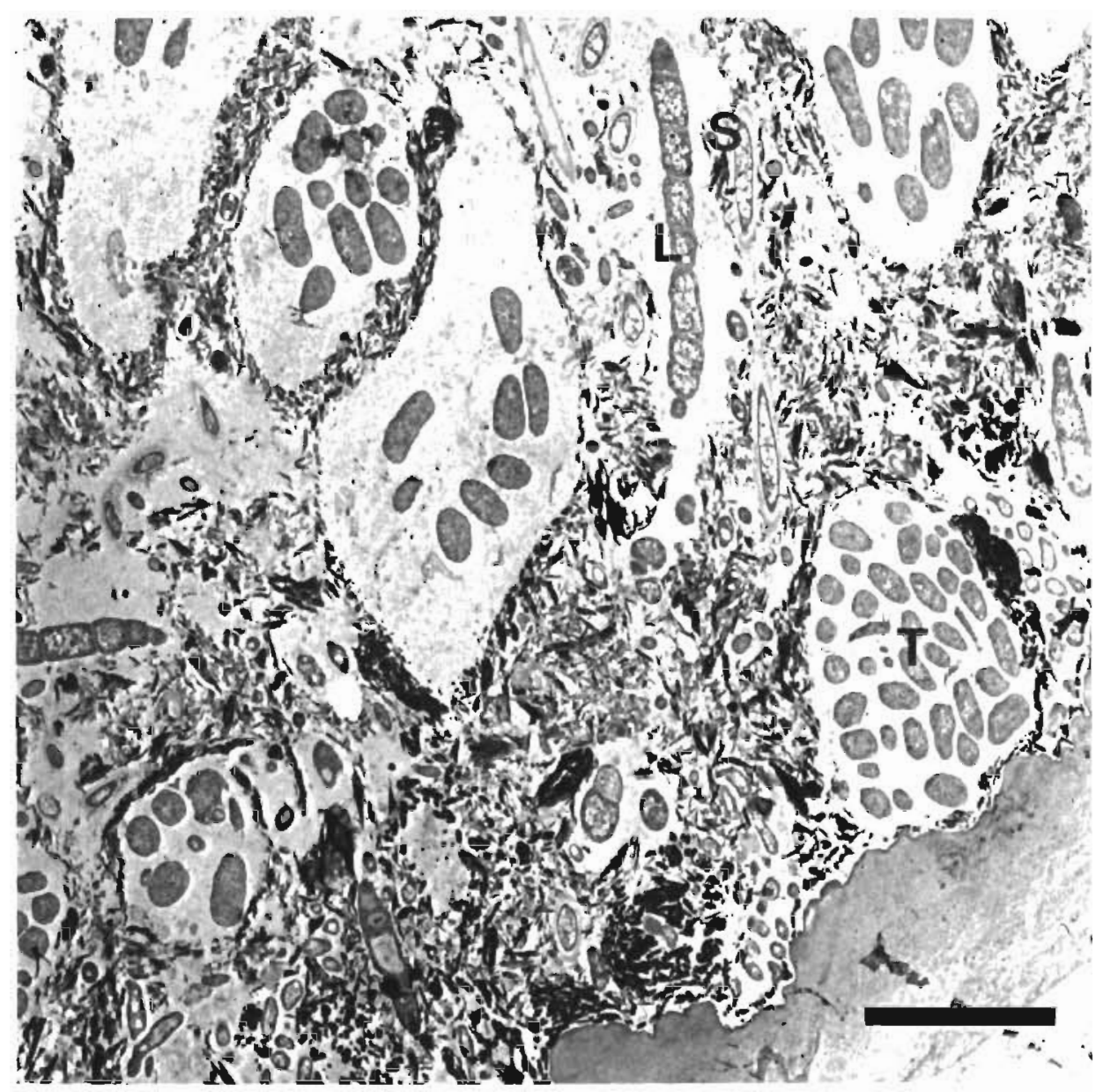

Fig. 2. Bacterial layer on the cuticle of Halicryptus spinulosus. Several microcolonies of Thiobacillus-like bacteria (T), filaments of the Leucothrix/Thiothrix-type (L) and a sheath-forming type (S) are seen in addition to numerous smaller bacteria and mineral depositions. TEM; scale bar: $5 \mu \mathrm{m}$ 

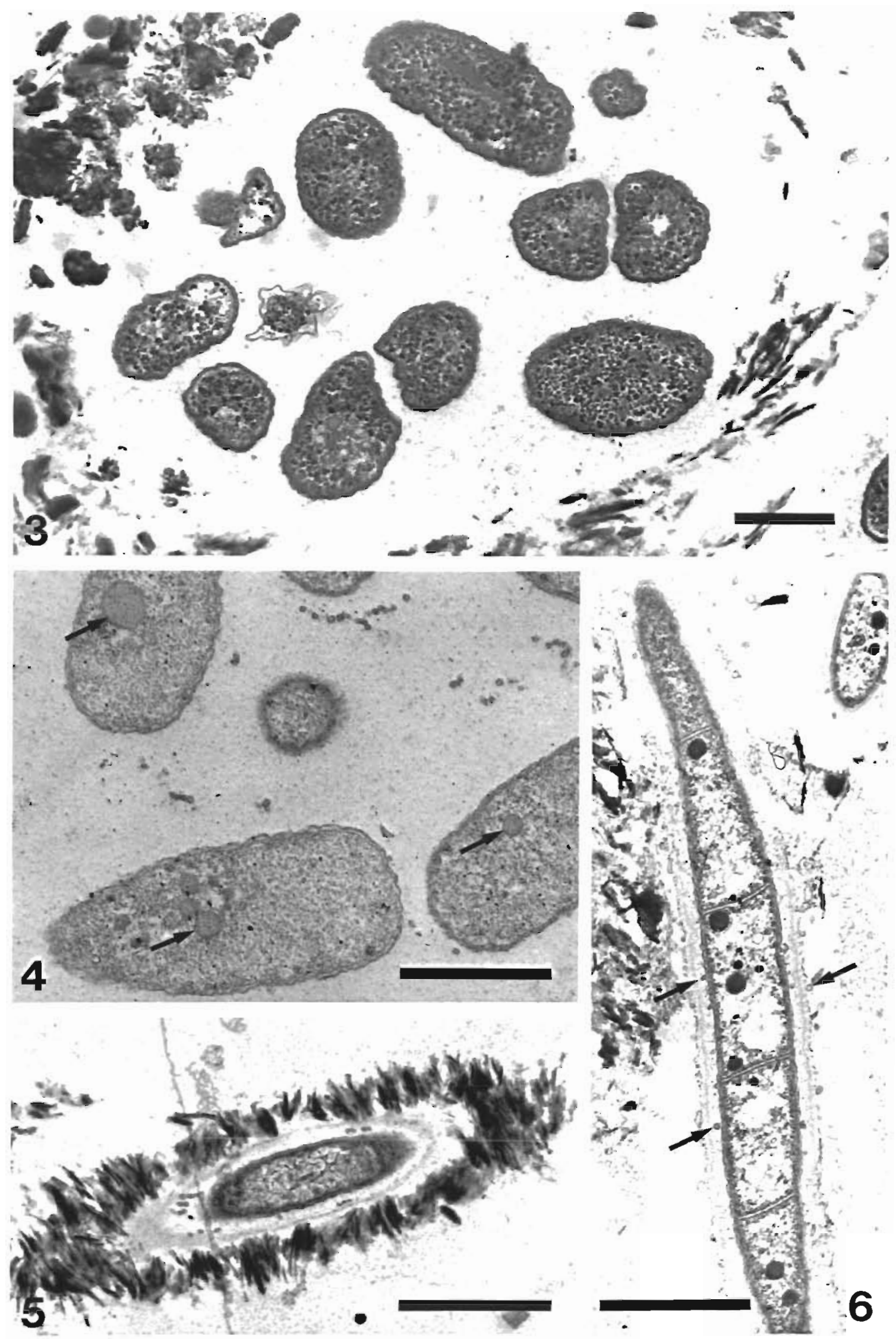

Figs. 3 to 6. TEM reproductions of bacteria on Halicryptus spinulosus cuticle. Fig. 3. Microcolony of Thiobacillus-like bacteria surrounded by mineral depositions; note rippled appearance of cell surface; scale bar: $1 \mu \mathrm{m}$. Fig. 4 . Thiobacillus-like bacteria showing undulating cell wail and polyhedral bodies (arrows); scale bar: $1 \mathrm{um}$. Fig. 5 . Cross-section through a sheath-forming filamentous bacterium (Type c), covered by a layer of disk-like crystals; scale bar: 1 um. Fig. 6 . Sheath-forming filamentous bacterium (Type c) showing formation of vesicles outside cell wall (arrows); note radial fine structure of sheath; scale bar: 1 um 


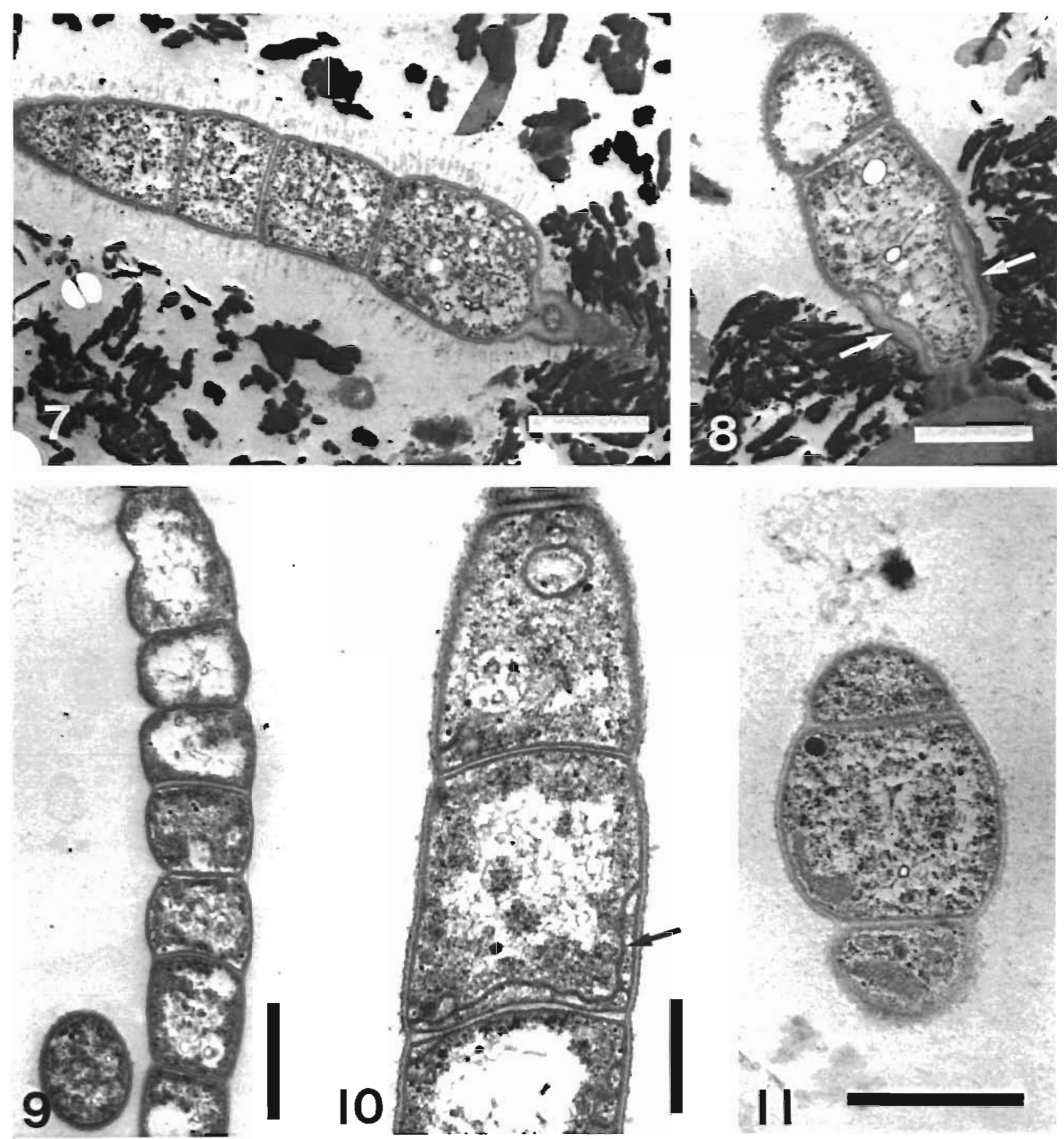

Figs. 7 to 11. TEM reproductions of bacteria on Halicryptus spinulosus cuticle. Fig. 7. Leucothrix/Thiothrix-like filament with holdfast. Fibrous extensions of cell wall radiate from basal cells; scale bar: $1 \mu \mathrm{m}$. Fig. 8 (as Fig. 7 ). In basal cell excretion of electrondense holdfast material is indicated by arrows; in this region the periplasmatic space is remarkably widened; a dense mineral deposition has occurred around the holdfast; scale bar: $1 \mu \mathrm{m}$. Fig. 9. Leucothrix/Thiothrix-like filament with rounded-up cells (probably stages in the formation of gonidia); a coccoid bacterium, most likely a separated gonidium, lies outside the filament; scale bar: $1 \mu \mathrm{m}$. Fig. 10. Leucothrix/Thiothrix-type filament showing internal membranes parallel to the cytoplasmic membrane (arrows); scale bar: $0.5 \mu \mathrm{m}$. Fig. 11. Bacterial cell resembling a gonidium of Leucothrix/Thiothrix after cross wall formation; scale bar: 1 um 


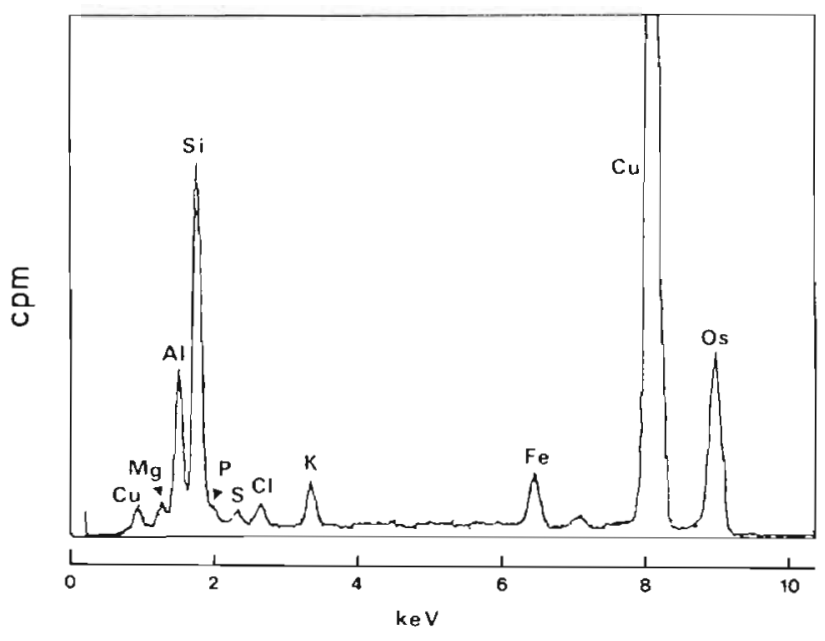

Fig. 12. Relative elemental. composition of mineral depositions around bacteria on the cuticle of Halicryptus spinulosus. Peaks of osmium and copper result from sample preparation.

\section{$\mathrm{X}$-ray microanalysis}

Disk-like crystals of mineral depositions are present throughout the bacterial layer, predominantly at the edge of microcolonies of the rod-shaped bacteria, around holdfasts or around single filaments. X-ray microanalysis showed the relative distribution of elements in these depositions (Fig. 12). Silicon, aluminium, iron, potassium, magnesium, and chlorine (in order of frequency) were the dominant elements. The sulphur content of bacterial storage granules was compared with that of the surrounding cytoplasm. No accumulation of sulphur was measured in the granules.

\section{Enzyme assay}

The activity of ribulose-1,5-bisphosphate carboxylase in homogenized tissues of the body wall of Halicryptus spinulosus showed a low carbon dioxide fixation rate (Table 1). Control assays, i.e. assays without added substrate, ribulosebisphosphate, also revealed measurable fixation of carbon dioxide, due to other carboxylizing reactions. This is not unusual: marine invertebrates from at least 14 phyla are able to incorporate carbon dioxide (Hammen \& Osborne 1959). One of the possible reactions is the carboxylation of phosphoenolpyruvate or of pyruvate to oxalacetate.

\section{Isotopes}

Homogenized tissues of Halicryptus spinulosus and Arctica islandica, and a sample of sediment from the collection site, were investigated for the ratio of stable
Table 1 Halicryptus spinulosus. Ribulose-1,5-bisphosphate carboxylase activity in homogenized body wall tissues (5 individuals) compared with a homogenate of the red algae Phycodris rubens, prepared in the same way

\begin{tabular}{|lc|}
\hline Species & $\begin{array}{c}\text { Ribulose-1,5-bisphosphate } \\
\text { carboxylase activity } \\
\mathrm{nmol} \mathrm{CO} \text { (g wet wt) }^{-1} \mathrm{~h}^{-1}\end{array}$ \\
\hline $\begin{array}{l}\text { Halicryptus spinulosus } \\
\text { Phycodris rubra }\end{array}$ & $\begin{array}{r}1.5,2.1,0,0,0 \\
116.6\end{array}$ \\
\hline
\end{tabular}

carbon and nitragen isotopes. The sample of $A$. islandica, with removed guts, served as comparison, because the investigations of Spiro et al. (1986) had shown that this species contains no bacterial symbionts. The carbon and nitrogen isotope ratios in the animals were similar, and they differed significantly from the values in the sediment (Table 2).

The $\delta^{13} \mathrm{C}$-value of the organic fraction of the sediment is remarkably low, indicating high chemoautotrophic activity. The animal samples are significantly less depleted in ${ }^{13} \mathrm{C}$ than the sediment. This excludes significant carbon transfer between chemoautotrophic bacteria and tissues of Halicryptus spinulosus.

Table 2. Halicryptus spinulosus and Arctica islandica. Ratios of stable carbon $\left({ }^{13} \mathrm{C} /{ }^{12} \mathrm{C}\right)$ and nitrogen $\left({ }^{15} \mathrm{~N} /{ }^{14} \mathrm{~N}\right)$ isotopes in tissues, and in organic fraction of sediment from the sampling site in Kiel Bight (Dec 1986). Values refer to the PDB $\left({ }^{13} \mathrm{C}\right)$ and air $\left({ }^{15} \mathrm{~N}\right)$ standards

\begin{tabular}{|lcc|}
\hline Sample & $\begin{array}{c}\delta^{13} \mathrm{C} \\
(\% 0)\end{array}$ & $\begin{array}{c}\delta^{15} \mathrm{~N} \\
(\%)\end{array}$ \\
\hline $\begin{array}{l}\text { Halicryptus } \\
\text { spinulosus } \\
\quad(n=3)\end{array}$ & -20.1 & +18.3 \\
Arctica & -18.6 & +16.7 \\
$\quad$ islandica & -16.2 & +16.6 \\
$\begin{array}{l}\text { Organic fraction of sediment } \\
\text { from sampling site }\end{array}$ & -16.1 & +13.5 \\
& -28.5 & +9.7 \\
\hline
\end{tabular}

\section{DISCUSSION}

The bacterial layer on the cuticle of Halicryptus spinulosus, also mentioned by Moritz (1971), can be compared with similar features of other marine invertebrates. Since the cuticle itself is never penetrated by the bacterial epibionts, this association differs from cases where subcuticular or intracuticular bacterial symbionts were found. Such symbioses have been described for nematodes (Ott et al. 1982), oligochaetes (Dubilier 1986, Giere \& Langheld 1987), polychaetes (Hausmann 1982), and echinoderms (Holland \& Nealson 1978). The situation in $H$. spinulosus appears similar to that in the pompeii worm Alvinella popejana 
(Desbruyères et al. 1983, Gaill et al. 1984), or to the microbial mats on the periostracum of thermal vent mussels (Jannasch \& Wirsen 1981).

Some of the bacteria observed on Halicryptus spinulosus are morphologically conspicuous, and a taxonomic approach can be attempted:

(a) The large rods occurring in microcolonies possess 2 features characteristic of the genus Thiobacillus: the rippled cell surface and the polyhedral bodies. The first is a prominent feature of most Thiobacillus species (Shively et al. 1970), and may also occur in some other bacteria. The presence of polyhedral bodies or carboxysomes provides strong evidence for chemoautotrophic activity, as these structures were shown to contain the enzyme ribulose-1,5-bisphosphate carboxylase (Shively et al. 1973). They have been found only in Thiobacillus, Nitrosomonas and many cyanobacteria (Schlegel 1985). As nitrifying bacteria and cyanobacteria contain complex internal membrane systems, which are not present in the large rods observed here, thiobacilli are the most probable taxonomic position for this type.

The filamentous organisms of Type (b) closely correspond to morphological descriptions of the genus Leucothrix (Brock \& Conti 1969). The variable thickness of cells within one filament, formation of rounded cells and gonidia, tubular invaginations of the cytoplasmatic membrane, presence of a holdfast and absence of a sheath are characteristics of this genus that fit well to the filaments observed here. Leucothrix is generally described as growing in rosettes. This feature was absent in our study, an observation also made by Jannasch \& Wirsen (1981) for very similar filaments on the periostracum of thermal vent mussels. Leucothrix is a common epiphyte on marine algae, also found on benthic marine Crustacea and on fish eggs (Johnson et al. 1971). The taxonomic relation between Leucothrix and Thiothrix is still uncertain, and both species cannot be distinguished when sulphur globules are absent (Brock 1981).

Only few microscopic descriptions of sheath-forming filamentous bacteria resembling Type (c) exist. There is a morphological similarity to the microorganisms which produce bulking sludge in sewage plants. Eikelboom (1975) described 2 types of sheath-forming bacteria, Type 1702 and Haliscomenobacter hydrossis, both of which form small, straight or slightly bent filaments of comparable diameter. Deinema et al. (1977) give TEM information on 4 strains of $H$. hydrossis, of which 2 strongly resemble the type observed on Halicryptus spinulosus. Comparable filamentous bacteria have been observed in planktonic water samples from the Baltic Sea (Schmaljohann 1984). Another possible taxonomic position for these bacteria is among Flexibacteriales, either Flexithrix dorotheae (Lewin 1970a) or
Herpetosiphon sp. (Lewin 1970b), which are both marine sheath-forming species.

Composition and appearance of the mineral depositions in the bacterial layer indicate that some kind of alumino-silicate mineral is deposited, rather than the ferric or manganese oxides typical of the SphaerotilusLeptothrix group and of thermal vent microbial mats (Jannasch \& Wirsen 1981). The precipitation of silicate minerals could possibly be explained by acid production and the development of a $\mathrm{pH}$ gradient surrounding the bacteria. Presuming that the bacterial layer consists largely of bacteria of the genera Thiobacillus and Leucothrix/Thiothrix, these organisms might be able to oxidize reduced sulphur compounds to sulphate, resulting in an acidification of the medium.

Homogenized body-wall tissue of Halicryptus spinulosus shows activity of ribulose-1,5-bisphosphate carboxylase, an important enzyme of the Calvin-Benson cycle, thus demonstrating chemoautotrophic activity of bacterial origin in the animal tissues. Compared to marine invertebrates containing symbiotic bacteria, however, these activities are low. Gill tissues of Myrtea spinifera (Spiro et al. 1986) and whole individuals of Phallodrilus leukodermatus (Felbeck et al. 1983) showed a carbon dioxide fixation rate between 100 and more than 3000 times higher than $H$. spinulosus. This enzyme has not been found in animal tissue lacking symbionts (Spiro et al. 1986). The low activity in the worms may be attributed to the fact that they were maintained for several days out of the sediment. This treatment was shown to reduce carboxylase activity in Pogonophora (Southward et al. 1986). It is important to note that the bacterial cells constitute only a small percentage of the total homogenized tissue compared to the other invertebrates mentioned.

The ratio of the stable nitrogen isotopes ${ }^{15} \mathrm{~N} /{ }^{14} \mathrm{~N}$ also serves for an interpretation of the relation between marine invertebrates and associated bacteria. Heterotrophic processes in subsequent steps within a food chain tend to increase the ${ }^{15} \mathrm{~N}$ isotopes in animal tissues (Rau 1981). The range for heterotrophic marine animals is between +7 and $+20 \%$ (Wada 1980), in contrast to marine phytoplankton with a range of +2 to $+8 \%$. If tissue samples from marine animals are significantly depleted in ${ }^{15} \mathrm{~N}$ compared with other tissues from the same organisms or with related organisms from the same habitat, a nutrition on the basis of chemoautotrophic bacteria is probable. This was shown for hydrothermal vent animals containing symbiotic bacteria with $\delta^{15}$-values between +2 and $+10 \%$ (Rau 1981) and for animals from abyssal saline seep communities in the Gulf of Mexico, which were even more depleted in ${ }^{15} \mathrm{~N}$ $\left(\delta^{15} \mathrm{~N}\right.$-values between -9 and $-2 \%$ ) (Paull et al. 1985). The role of bacteria in the nutrition of Alvinella pompejana has been demonstrated by Desbryuères et al. 
(1983), who found $\delta^{15} \mathrm{~N}$-values of about $+6 \%$. Our $\delta^{15} \mathrm{~N}$-values for Halicryptus spinulosus, +16.6 to $18.3 \%$, and $+13.5 \%$ for Arctica islandica, are within the range expected for heterotrophic animals. Ankar \& Sigvaldadottir (1981) presume $H$. spinulosus to be carnivorous; this is supported by our ${ }^{15} \mathrm{~N}$-values.

The ratio of the stable carbon isotopes in the tissues of an animal is usually close to that of its food source, normally slightly enriched in the ${ }^{13} \mathrm{C}$-isotope (Galimov 1985, Spiro et al. 1986). Chemoautotrophic bacteria are able to discriminate against ${ }^{13} \mathrm{C}$ in such a way that their cell carbon has $\delta^{13} \mathrm{C}$-values about $25 \%$ below the available bicarbonate (Ruby et al. 1987). Symbiotic associations between chemoautotrophic bacteria and marine invertebrates usually show $\delta^{13} \mathrm{C}$-values ranging from -23 to $-46 \%$, depending on the source of inorganic carbon, the extent of internal recycling of $\mathrm{CO}_{2}$ temperature and the percentage of other food sources (Spiro et al. 1986). The $\delta^{13} \mathrm{C}$-value of Halicryptus spinulosus is close to values that are typical for benthic animals without symbionts like Arctica islandica from the same habitat, and the bivalves investigated by Spiro et al. (1986). Therefore, the epibacteria probably do not contribute significantly to the nutrition of $H$. spinulosus.

The bacteria encountered obviously do not act as symbionts which are found on some other marine invertebrates benefitting from these organisms and thus enhancing their ability to survive in sulfide-rich environments. Although there are probably sulfide-oxidizing bacteria on the cuticle of Halicryptus spinulosus, judging by the morphology of the bacteria and by the presence of a small amount of ribulose-1,5-bisphosphate carboxylase activity, the worms do not benefit from the bacterial association in terms of nutrition.

Any direct 'advantage' of the association of bacteria for Halicryptus spinulosus is uncertain. It may be assumed that the bacteria are able to protect the worms against hydrogen sulfide to some degree when sufficient oxygen or nitrate is available, since these bacteria, like Thiobacillus or Leucothrix/Thiotrix are aerobes. But this concerns only animals that live in at least partly oxygenated sediment, or at the boundary between oxic and anoxic sediment layers. Detoxification must be accomplished entirely by the worms themselves, when their environment becomes anoxic or when they burrow in deeper anoxic sediments, as can be observed in the field. Laboratory experiments have shown that $H$. spinulosus is able to survive high concentrations of hydrogen sulfide $(0.2 \mathrm{mM})$ in incubation water for at least $40 \mathrm{~d}$ (Oeschger 1987). These observations provide evidence that the worm must rely on its own sulfide metabolism. When incubated in hydrogen sulfide-containing seawater, $H$. spinulosus turns completely black. Possible involvement of hemerythrin in the detoxification process might serve as a basis for further investigations.

Acknowledgements. Part of this paper was included in the Ph. D. thesis of the first author, who thanks Professor $\mathrm{Dr} H$. Theede for advice and helpful discussions. Methodological support was received from the following colleagues: Dr W. Reichardt, Institut für Meereskunde, Kiel, helped with determining the activity of ribulose-1,5-bisphosphate carboxylase; Dr E. Faber, Bundesanstalt für Geowissenschaften und Rohstoffe, Hannover, with the analysis of stable carbon isotopes; Professor Dr Sieck and Dr Roos, Bundesanstalt für Milchforschung, Kiel, with the analysis of stable nitrogen isotopes; Dr Czank, Mineralogisches Institut der Universität Kiel, assisted in X-ray microanalysis. For comments and discussions on the manuscript we thank Dr P. Dando and Dipl.-Biol. M. Seaman.

\section{LITERATURE CITED}

Ankar, S., Sigvaldadottir, E. (1981). On the food composition of Halicryptus spinulosus von Siebold. Ophelia 20: 45-51

Brock, T. D. (1981). The genus Leucothrix. In: Starr, M. P., Stolp, H., Trüper, H. G., Balows, A., Schlegel, H. (eds.) The prokaryotes, Vol. I. Springer-Verlag, Berlin, p. 401-408

Brock, T D., Conti, S. F. (1969). Electron microscope studies on Leucothrix mucor. Arch. Mikrobiol. 66: 79-90

Dando, P. R., Southward, A. J., Southward, E. C., Terwilliger, N. B., Terwilliger, R. C. (1985). Sulphur-oxidizing bacteria and haemoglobin in gills of the bivalve mollusc Myrtea spinifera. Mar. Ecol. Prog. Ser. 23: 85-98

Deinema, M. H., Henstra, S., Werdmüller von Elgg, E. (1977). Structural and physiological characteristics of some sheathed bacteria. Antonie van Leeuwenhoek 43: 19-29

Desbruyères, D., Gaill, F., Laubier, L., Prieur, D., Rau, G. H. (1983). Unusual nutrition of the 'Pompeil worm' Alvinella pompejana (polychaetous annelid) from a hydrothermal vent environment: SEM, TEM, ${ }^{13} \mathrm{C}$ and ${ }^{15} \mathrm{~N}$ evidence. Mar. Biol. 75: 201-205

Dubilier, N. (1986). Association of filamentous epibacteria with Tubificoides benedii (Oligochaeta: Annelida). Mar Biol. 92: 285-288

Eikelboom, D. H. (1975). Filamentous organisms observed in activated sludge. Wat. Res. 9: 365-388

Felbeck, H., Liebezeit, G., Dawson, R., Giere, O. (1983). CO fixation in tissues of marine oligochaetes (Phallodrilus leukodermatus and $P$. planus) containing symbiotic, chemoautotrophic bacteria. Mar Biol. 75: 187-191

Gaill, F., Desbruylères, D., Prieur, D., Gourret, J. P. (1984). Mise en evidence de communautés bactériennes épibiontes du 'Ver de Pumpéi' (Alvinella pompejana). C.r. hebd Séanc. Acad. Sci. Paris 298 (Serie III): 553-558

Galimov, E. M. (1985). The biological fractionation of isotopes. Academic Press Inc., New York

Giere, O., Langheld, C. (1987). Structural organisation, transfer and biological fate of endosymbiotic bacteria in gutless oligochaetes. Mar. Biol. 93: 641-650

Glover, H. E. Morris, I. (1979). Photosynthetic carboxylating enzymes in marine plankton. Limnol. Oceanogr. 24 $510-519$

Hammen, C. S. Osborne, P. J. (1959). Carbon dioxide fixation in marine invertebrates: a survey of major phyla. Science 139: 1409-1410

Hausmann, K. (1982). Elektronenmikroskopische Untersuchungen an Anaitides mucosa (Annelida, Polychaeta). 
Cuticula und Cilien, Schleimzellen und Schleimextrusion. Helgoländer Meeresunters. 35: 79-96

Heritage, A. D., Foster, R. C. (1984). Catalase and sulfur in the rice rhizosphere: an ultrastructural histochemical demonstration of a symbiotic relationship. Microb. Ecol. 10: $115-121$

Holland, N. D. Nealson, K. H. (1978). The fine structure of the echinoderm cuticle and subcuticular bacteria of echinoderms. Acta Zool. (Stockh.) 59: 169-185

Jannasch, H. W., Wirsen, C. O. (1981). Morphological survey of microbial mats near deep-sea thermal vents. Appl. environm. Microbiol. 41: 528-538

Johnson, P. W., Sieburth, J. McN., Sastry, A., Arnold, C. R., Doty, M. S. (1971). Leucothrix mucor infestation of benthic Crustacea, fish eggs and tropical algae. Limnol. Oceanogr. 16: $962-969$

Joshi, M. M., Hollis, J. P. (1977). Interaction of Beggiatoa and rice plant: detoxification of hydrogen sulfide in the rice rhizosphere. Science 195: 179-180

Lewin, R. A. (1970a). Flexithrix dorotheae gen. et sp. nov (Flexibacteriales); and suggestions for reclassifying sheathed bacteria. Can. J. Microbiol. 16: 511-515

Lewin, R. A. (1970b). New Herpetosiphon species (Flexibacteriales). Can. J. Microbiol. 16: 517-520

Moritz, K. (1971). Elektronenmikroskopische und physiologische Untersuchungen an Priapuliden, Sipunculiden und Echiuriden. Ph. D. thesis, University of Kiel

Oeschger, R. (1987). Vergleichende Untersuchungen zur biotopbedingten Langzeit-Anaerobiose und Schwefelwasserstoff-Resistenz bei einigen marinen Wirbellosen aus der Ostsee. Ph. D. thesis, University of Kiel

Oeschger, R., Theede, H. (1988). Use of biochemical features of macrobenthic species as indicators of long-term oxygen deficiency. Kieler Meeresforsch., Sonderh. 6 (in press)

Ott, J., Rieger, G., Rieger, R., Enderes, F. (1982). New mouthless interstitial worms from the sulphide system: symbiosis with prokaryotes. P. S. Z. N. I. MaI. Ecol. 3: 313-333

Paull, C. K., Jull, A. J. T., Toolin, L. J., Linick, T. (1985). Stable isotope evidence for chemosynthesis in an abyssal seep community. Nature, Lond. 317: 709-711
Powell, E. C., Crenshaw, M. A., Rieger, M. (1979). Adaptations to sulfide in the meiofauna of the sulfide system. I. ${ }^{35} \mathrm{~S}-$ sulfide accumulation and the presence of a sulfide detoxification system. J. exp. mar Biol. Ecol. 37: 57-79

Rau, G. H. (1981). Low ${ }^{15} \mathrm{~N} /{ }^{14} \mathrm{~N}$ in hydrothermal vent animals: ecological implications. Nature, Lond. 289: 484-485

Ruby, E. G., Jannasch, H. W., Deuser, W. G. (1987). Fractionation of stable carbon isotopes during chemoautotrophic growth of sulfur-oxidizing bacteria. Appl environ. Microbiol. 53: 1940-1943

Schlegel, H. G. (1985). Allgemeine Mikrobiologie, 6th ed. Gustav Thieme Verlag, Stuttgart

Schmaljohann, R. (1984). Morphological investigations on bacterioplankton of the Baltic Sea, Kattegat and Skagerrak. Botanica mar. 27: 425-436

Shively, J. M., Decker, G. L., Greenawalt, J. W. (1970). Comparative ultrastructure of the Thiobacilli. J. Bacteriol. 101: 618-627

Shively, J. M., Ball, F., Brown, D. H., Saunders, R. E. (1973). Functional organelles in prokaryotes: polyhedral inclusions (carboxysomes) of Thiobacillus neapolitanus. Science 182: $584-586$

Southward, A. J., Southward, E. C., Dando, P. R., Barrett, R. L., Ling, R. (1986). Chemoautotrophic function of bacterial symbionts in small Pogonophora. J. mar. biol. Ass. U. K. 66: $415-437$

Spiro, B., Greenwood, P. B., Southward, A. J., Dando, P. R. (1986). ${ }^{13} \mathrm{C} /{ }^{12} \mathrm{C}$ ratios in marine invertebrates from reducing sediments: confirmation of nutritional importance of chemoautotrophic endosymbiotic bacteria. Mar Ecol. Prog. Ser. 28: 233-240

Theede, H., Ponat, A., Hiroki, K., Schlieper, C. (1969). Studies on the resistance of marine bottom invertebrates to oxygen-deficiency and hydrogen sulphide. Mar. Biol. 2: 325-337

Wada, E. (1980). Nitrogen isotope fractionation and its significance in biogeochemical processes occurring in marine environments. In: Goldberg, E. D., Horribe, Y., Sasuhashi, K. (eds.) Isotope marine chemistry. Uchida Rokakuho Tokyo, p. 375-398 